\title{
Children and Wild Foods in the Context of Deforestation in Rural Malawi
}

\author{
H. Maseko ${ }^{1} \cdot$ Charlie M. Shackleton $^{1}$ (D) $\cdot$ J. Nagoli $^{2} \cdot$ D. Pullanikkatil $^{1}$
}

Published online: 8 November 2017

(C) Springer Science+Business Media, LLC 2017

\begin{abstract}
There is growing recognition of the contribution of wild foods to local diets, nutrition, and culture. Yet disaggregation of understanding of wild food use by gender and age is limited. We used a mixed methods approach to determine the types, frequencies, and perceptions of wild foods used and sold by children in four villages in southern Malawi that have different levels of deforestation. Household and individual dietary diversity scores are low at all sites. All households consume one or more wild foods. Across the four sites, children listed 119 wild foods, with a wider variety at the least deforested sites than the most deforested ones. Older children can name more wild foods than younger ones. More children from poor households sell wild foods than from well-off households. Several reasons were provided for the consumption or avoidance of wild foods (most commonly taste, contribution to health, limited alternatives, hunger, availability, local taboos).
\end{abstract}

Keywords Age · Children - Consumption frequency · Diversity $\cdot$ Food security $\cdot$ Wild foods $\cdot$ Malawi

\section{Introduction}

Wild foods are components of diets and local economies the world over, from rural Africa (Ncube et al. 2016) to urban USA (McLain et al. 2014). Whilst most people eat wild foods,

Charlie M. Shackleton

c.shackleton@ru.ac.za

1 Department of Environmental Science, Rhodes University, Grahamstown 6140, South Africa

2 WorldFish - Malawi, P. O Box, 229 Zomba, Malawi diversity and frequency vary greatly between and within households, villages, countries, and regions. Thus, while for some the collection or consumption of wild foods may be a daily occurrence, for others it is a seasonal or rare delicacy. Nonetheless, with over 7000 edible plant species and a similar number of edible animal species, the contribution of wild foods to peoples' diets should not be underestimated (Bharucha and Pretty 2010). In many regions wild foods contribute significantly to household food security, dietary diversity, and nutritional wellbeing (Kajembe et al. 2000) because they add diversity to the mostly starch-based, staple diets of households throughout the world (Uusiku et al. 2010; Powell et al. 2011; Ncube et al. 2016). Without wild foods, global and national levels of food insecurity would be significantly higher (Bharucha and Pretty 2010) and consequently they need to be an integral part of any international and local policies and strategies to address food insecurity.

The high variation in use and acceptance of wild foods is a reflection of their availability and local food cultures (FAO 2010). In many regions diets are in transition as a consequence of globalisation and increasing market access (Pingali 2007; Damman et al. 2008; Ncube et al. 2016). The former is associated with declines in agrobiodiversity, dietary diversity, and knowledge of wild foods and local cultivars. The latter brings exposure to and convenience of new foods that may be easily and constantly available (van Vliet et al. 2015a). At a local scale changes in knowledge and consumption patterns of wild species have been linked to land use change, deforestation, migration from rural areas, and mass schooling (Broegaard et al. 2016; Sylvester et al. 2016).

Land use change and deforestation are particularly pertinent to debates on ecosystem services provision, food security, and the role of wild foods. The expansion of agriculture is often at the expense of forests and other natural landscapes that are noteworthy sources of ecosystem services, including 
wild foods that diversify diets and contribute essential micronutrients (Poppy et al. 2014). Powell et al. (2011) showed that rural households in Tanzania close to patches of trees or forests had higher dietary diversity and more nutrient dense foods than households far from patches of trees. In Cameroon, Tata-Ngome (2016) found that household food security was greatest in the least deforested zones. Similarly, Ickowitz et al. (2013) reported, after examination of national scale data, that there was a positive relationship between tree cover and dietary diversity and fruit and vegetable consumption for 21 African countries.

Yet, the nexus between forests, land use change, wild foods and nutrition are poorly understood or explored (Broegaard et al. 2016). This is especially so at the local scale, where the benefits of land use change and agricultural intensification are not uniformly enjoyed. Many households continue to experience limited access to land, have to work on lands of poor quality or are economically marginalised and therefore unable to purchase the necessary inputs for intensive agriculture. Such households therefore depend on a diversity of food sources, amongst which wild foods remain key. And there are also those who simply prefer wild foods for their taste or cultural meanings. Consequently, changes in land use that deplete the diversity or abundance of wild foods potentially jeopardise food security and nutrition of some households. For example, van Noordwijk et al. (2014) showed that consumption of bushmeat and wild vegetables declined markedly, as did protein intake, with agricultural expansion and intensification in northern Laos, whilst Timko (2013) argued that in Malawi, forest resources need to be secured to allow many rural households to cope with the ravages of HIV/AIDS.

Nonetheless, there is some academic debate on how deforestation influences wild food availability. Wild food use varies spatially and temporally because availability and use are affected by seasonality, abundance, preferences among different socioeconomic groups (Garcia 2006; Uusiku et al. 2010; Heubach et al. 2011), climatic changes, and environmental degradation (Kamanga et al. 2009). Some argue that forest cover influences availability as noted by studies that reveal a decline in the diversity of wild foods in the diet during the conversion of complex woodland systems to simplified crop land or reduction of forests and woodlands (Scoones et al. 1992; Jonhson et al. 2013) even though this does not apply to all wild food categories. For instance, in three Tanzanian villages there is a negative correlation between the diversity of edible plants being eaten and the degree of deforestation (Scoones et al. 1992) with higher tree cover associated with high diversity of wild food. Similar findings were found in Malawi (Jonhson et al. 2013), Tanzania (Powell et al. 2011) and in Kenya where the last 20 years of land use change to agricultural systems have reduced the availability of Mbeere wild food collection and use (Scoones et al. 1992). Recently,
Ickowitz et al. (2013) reported a strong positive relationship between forest cover and household nutrition.

On the other hand, Campbell (1987) indicated that in some contexts deforestation may not significantly affect availability of selected wild fruits because people tend to be selective during land clearing for agricultural production. He showed that the abundance of fruit trees, as measured by percentage canopy cover, showed no relationship to frequency of wild fruits used. This indicates that people living in climax woodland or other complex systems are not basing selection of fruits on mere abundance of fruit trees; they are actively selecting for certain fruit species (Campbell 1987; Kalaba 2007). In many African countries rural households intentionally retain fruit trees in their fields or intensify their density around the homestead (Schreckenberg 1999; Kalaba 2007; Shackleton et al. 2008). In Malawi, the prevalence of cultural restrictions governing the use and exploitation of indigenous trees enables the maintenance of wild fruit species such as Parinari curatellifolia, Strychnos cocculoides, and Uapaca kirkiana around homesteads or crop fields (Syampungani et al. 2009). Thus, despite significant changes in woodlands and their use, their contribution to maintaining health and providing people's basic needs appears to remain important (Lowore 2006), albeit quantities available and consumed may be affected. In terms of wild vegetables, many species are prominent 'weeds' in agricultural fields and so are promoted in more human-dominated landscapes (Powell et al. 2014; Kidane et al. 2015). This points to the need to disaggregate responses by different food types.

In understanding use of wild foods and their contribution to diets and food security it is imperative that all user-groups are considered. While considerable research has looked at poor rural households as major beneficiaries of wild foods (Paumgarten and Shacketon 2009; Heubach et al. 2011; Maroyi 2011), such data need to be further disaggregated using other social classifications such as age, gender, education, and location. Children are often overlooked in this dynamic and rarely feature in dietary surveys and even ethnobotanical research on wild foods (McGarry and Shackleton 2009a; van Vliet et al. 2015b; Sylvester et al. 2016). Yet they are important actors in some situations because they spend a great deal of time outdoors interacting with nature (Alexander et al. 2015) and are also direct collectors and consumers of wild foods (McGarry and Shackleton 2009a; van Vliet et al. 2015b; Sylvester et al. 2016). Some wild food species are regarded as solely or largely children's foods (McGarry and Shackleton 2009a). Some children engage in collection and sale of wild foods to earn income for themselves or their families (Challe and Price 2009; McGarry and Shackleton 2009a). Children's use of wild foods is often just part of the family's broader food procurement strategies (Setalaphruk and Price 2007; Sylvester et al. 2016). But in some instances, such as child-headed households, or where parents are migrant 
labourers for long periods, or too infirm or elderly to farm or generate income, children may play a leading role in sourcing wild foods (Setalaphruk and Price 2007; Challe and Price 2009; McGarry and Shackleton 2009a). This is particularly common in areas with high HIV/AIDS rates.

Rural Malawi typifies many of these dynamics, which have impacts on local and national strategies to attain food security. Much of rural Malawi has high human population densities, underlying increasing needs for land for agriculture and high reliance on forest products (Kamanga et al. 2009; Timko 2013). Clearing land for subsistence and cash crop agriculture is a major driver of deforestation, with Malawi having one of the highest deforestation rates in sub-Saharan Africa, approximately $2.5 \%$ p.a. (Fisher et al. 2010; Ministry of Environment and Natural Resources 2010). Deforestation potentially reduces the supply of wild foods. For example, Maliro and Kwapata (2002) report how the richness and abundance of wild fruit trees declined with deforestation in southern Malawi. Simultaneously, Malawi has suffered high rates of HIV/AIDS, which have debilitated the labour supply in many households and increased dependence on forest resources (Timko 2013).

In Malawi, food security is typically seen as equivalent to adequate production of maize, the country's staple accounting for more than 60\% of total food production (Ecker and Qaim 2010). Standardised surveys indicate that the diets of Malawians are poorly diversified, with over $60 \%$ of total food consumption consisting of starchy food, primarily maize (Ecker and Qaim 2010; Chilimba et al. 2012), although few surveys have explicitly included wild foods. Undernourishment affects approximately 3.5 million people (one in five) (FAOSTAT 2017), $37 \%$ of children under the age of five are stunted, $3 \%$ are wasted, and $12 \%$ are underweight (Chirwa and Ngalawa 2008; Government of Malawi 2016). The situation is exacerbated by the high prevalence of HIV/AIDS (Department of Nutrition, HIV and AIDS 2009), and the high incidence of poverty. With such worrisome statistics attaining food security is a concern for policy-makers, health practitioners, and agriculturalists and yet strategies remain focused on promoting the availability of staple foods (Mazunda and Droppelmann 2012; Kerr et al. 2016) with a clear neglect of micronutrient sources.

Within this context, we present here a study of wild food procurement and consumption by children in four villages of differing deforestation status in southern Malawi. Specifically, we sought to answer the following questions: (1) What wild foods are used by children? (2) What is the frequency of consumption of wild foods by children? (3) What are the reasons children consume wild foods? And (4) are these patterns influenced by local level deforestation status?

Our study focused specifically on children. Harvesting of wild foods by adults has been covered in several studies (Cavendish 2000; Vaughan 2007; Shackleton and Gumbo
2010; Paumgarten and Shacketon 2009; Heubach et al. 2011; Maroyi 2011); however, research on harvesting of wild foods by children is limited. Children have usually been ignored in rural environmental research despite being a significant user group and are invisible actors in this field of research (Challe and Price 2009; McGarry and Shackleton 2009a; Alexander et al. 2015). In this regard, children's consumption of wild foods in their environments and during play (Campbell 1987; Garcia 2006), or as snacks and meals, is hardly quantified and explored despite the awareness that these foods may contribute significantly to their well-being (Lowore 2006; McGarry and Shackleton 2009a). We address this knowledge gap by focusing on children's as opposed to adults' harvesting activities.

\section{Study Area}

The study was conducted during later summer (Feb - May) 2013, in the Zomba District, southern Malawi, as part of a larger study examining ecosystem services trades-offs, namely "Attaining Sustainable Services from Ecosystems through Tradeoff Scenarios" or ASSETS (Poppy et al. 2014). As part of the larger project, four sites were selected along a gradient of woody vegetation cover and deforestation from Lake Chilwa in the east, through and beyond the Zomba forest reserve in the west (Table 1). Land use and cover images showing changes between 1990 and 2010 were used to make this categorisation.

Among the four villages (Makombe, Kasonga, Mtuluma, and Mpheta; Table 1), Kasonga has higher number of households who are better off compared to the rest, and Mpheta has the least number of better off households. Economic activities vary, but agriculture is the dominant occupation in all four sites.

The mean annual rainfall in Zomba is $2000 \mathrm{~mm}$, making it one of the wettest and agriculturally rich locations in Malawi (Ngongondo 2006). The economy of Zomba district is agrobased, with maize for subsistence and sale being the most common crop, along with tobacco as a cash crop in some areas (Zomba District Assembly 2009). Other common crops include rice, cassava, potatoes, beans, and pigeon peas. Livestock production is mainly for subsistence, based on cattle, goats, pigs and poultry (Zomba District Assembly 2009). The population density within the district is approximately 231 persons per $\mathrm{km}^{2}$. Formal employment is limited, and $24 \%$ of adult males and $28 \%$ of females in the district are illiterate (UN-HABITAT 2011).

\section{Methods}

A mixed methods approach was adopted in each village, using a combination of household 24-h dietary recall surveys, 
Table 1 Summary characteristics of the four study villages

\begin{tabular}{|c|c|c|c|c|}
\hline Attribute & Makombe & Kasonga & Mtuluma & Mpheta \\
\hline Area & Shire River Basin & Zomba Forest Reserve & Zomba Forest Reserve & Lake Chilwa Basin \\
\hline Coordinates & $x=728527 y=830935$ & $x=745591 y=830638$ & $x=742772 y=831352$ & $x=769814 y=831749$ \\
\hline Vegetation type & Mopane savanna & Semi-evergreen forest & Miombo savanna & Wetland and riparian fringe \\
\hline Extent of forest cover & Low & Medium-high & High & Low \\
\hline Deforestation rate & Low & High & Medium & Low \\
\hline No. of male-headed hhs & 96 & 96 & 38 & 307 \\
\hline No. of female-headed hhs & 25 & 33 & 17 & 90 \\
\hline No. of children ( $8-19$ years) & 299 & 293 & 134 & 1051 \\
\hline No. of very poor hhs ${ }^{\text {a }}$ & 63 & 0 & 38 & 51 \\
\hline No. of poor hhs ${ }^{\text {a }}$ & 45 & 42 & 13 & 251 \\
\hline No. of better off hhs ${ }^{\text {a }}$ & 13 & 87 & 4 & 5 \\
\hline Economic activities & $\begin{array}{l}\text { Quarrying, Timber production, } \\
\text { Agriculture (Maize and } \\
\text { Irish potatoes) }\end{array}$ & $\begin{array}{l}\text { Agriculture } \\
\text { (Cotton and maize), } \\
\text { Livestock production }\end{array}$ & $\begin{array}{l}\text { Agriculture (Maize, Cassava), } \\
\text { Small -scale businesses }\end{array}$ & $\begin{array}{l}\text { Agriculture (Rice, fisheries), } \\
\text { Small-scale businesses, } \\
\text { Livestock production }\end{array}$ \\
\hline
\end{tabular}

Education of children ${ }^{\mathrm{b}} \quad$ Primary completion rate ${ }^{\mathrm{c}}: 41.9 \%$ for Zomba district

Transition rate to secondary school ${ }^{\mathrm{d}}: 39 \%$ for Zomba District

${ }^{\mathrm{a}}$ (hh status was determined via participatory, self categorisation)

${ }^{\mathrm{b}} \mathrm{NSO}$ ( 2014)

${ }^{\mathrm{c}}$ Number of children attending the last class of primary school (excluding repeaters) divided by number of children of primary school completion age (age appropriate to final class of primary school)

${ }^{\mathrm{d}}$ Number of children attending the last class of primary school during the previous school year who are in the first class of secondary school during the current school year divided by number of children attending the class of primary school during the previous school year

participatory methods, key informant interviews, and focus group discussions. Standard $24 \mathrm{~h}$ recall methods were used to ascertain the number of meals eaten per day, the Household Dietary Diversity Score (HDDS) and the Individual Dietary Diversity Score (IDDS) (Swindale and Bilinsky 2006; FAO 2011). The person responsible for food preparation in the household, most commonly the mother or adolescent girls, was interviewed to provide details of all foods prepared in the household in the last $24 \mathrm{~h}$. These interviews were held firstly in the months of January and February during what are regarded as the end of the food insecure period and secondly in the months of March to April during periods of food security. Foods consumed were coded according to a set of 12 food groups and the HDDS calculated.

The participatory approaches included food diaries and transect walks with children in each village. After ethics approval was granted via Rhodes University and permission was granted for the work by each local village authority and the parents, 150 children (8-18 years old) were selected using a stratified sample across the four villages. Accounting for the different number of households in each village, every fourth house in Mphetha was sampled, every third one in Kasonga and Makombe, and every second one in Mtuluma. Each child within the target age cohort in a sample household was provided with an interactive food diary that they were encouraged to complete on a daily basis for two one-week periods. The first week was in February 2013 and the second in late April 2013, to represent food insecure and food secure periods, respectively. The purpose of the diary was explained to all members of the household and instructions and trial runs were conducted for each household individually. A local assistant from each village was also trained and helped to encourage and motivate completion of the diaries by visiting households every 1-2 days. Data on relative socioeconomic status of each household were available from the larger ASSETS study.

Transect walks were conducted with one or two groups of 3-8 children in each village. The route of each transect walk was planned to cover as many of the vegetation types and land use areas in and around each village as possible. Walks lasted between two and three hours in the afternoons (after school in the mornings). However, several female participants opted out partway through and so were not present for the entire walk. During the walk participants pointed out wild plants and animals that they consume, provided the local name and general information about the species, and how they catch or collect it and eat it. Samples of identified plants were collected for formal identification at the National Herbarium and Botanical Gardens in Zomba. The identification of wild animal species was done through local experts and desk research. The identification of birds was done with the help of the Bird Hunter's Association from Mpheta. The transect walks could only reveal the species available at that time and would not 
account for wild species collected in other seasons. In a few instances wild foods named by children could not be validated by community members or experts. For instance, bird names such as daniele and sisisi were only used by children and identification of these species could not be done. Meanwhile, plants such as lububa (Rumex abysinicus) were only known to children and not adults in the village, but could be identified by experts through the samples collected.

Focus group discussions were also conducted at each village. These consisted of general discussions and activities around wild foods with at least two groups comprising 8-15 children. Prior to the general discussion, each child was asked to list as many wild foods as they could within a three minute period. Thereafter, groups were separated by gender and open discussions were held about wild foods, where they are found, how they are accessed, and general attitudes towards them.

Quantitative data collected from the field were entered in Excel and imported into SPSS for analysis. Comparisons of continuous variables between villages were done via ANOVA, and between food secure and food insecure periods via a t-test. Proportion data were compared using a ChiSquared test.

\section{Results}

\section{Childrens' Diets in Rural Zomba}

At a household level women and older girls are responsible for the preparation of meals. The consumption and dominance of cereal-based diets were common during both food secure (FS) periods (Mar - Apr) and food insecure (FI) periods (Dec Feb). In the morning a typical meal was tubers or a processed cereal such as wholegrain porridge with or without any beverage, such as tea. In the afternoon/evening a child's typical meal consisted of a processed cereal, mostly nsima, with vegetables and/or pulses, and sometimes meat products. A meal of nsima, made from maize flour, was widely believed to be a satisfying meal regardless of the presence of other foods. Various African Leafy Vegetables (ALVs) and pulses were recorded as common side dishes taken to complement nsima and other grains. Data from the food diaries showed that common ALVs consumed by children across the four villages included leaves from pumpkins, green beans, and lentils and wild species such as Amaranthus, Bidens or Cleome. From the $24 \mathrm{~h}$ food recall, the percentage of children who consumed ALVs were 59\% in Makombe, $63 \%$ in Kasonga, $27 \%$ in Mtuluma, and 65\% in Mpheta.

There was no significant difference $(t=0.36 ; p>0.05)$ in the number of meals taken by children at home during the FS and FI periods, averaging above two in both (Table 2). During the FI period, a smaller group of households (4\%) only had one meal a day, while the lowest number of meals at household level during FS period was two. Children from Makombe, Mpheta, and Kasonga all received porridge (made from soya beans) at their school during school days, which added to the average number of meals taken by children in FS and FI periods. In Malawi, the School Feeding Programme was introduced in primary schools to accelerate the achievement of the Millennium Development Goal 2 on Education to increase enrollment, attendance, and retention of children in schools (Department of Nutrition, HIV, and AIDS 2009).

Despite the insignificant difference in the number of meals taken by children at home, children indicated that there was a difference in the quality of meals during the FI and FS periods; food eaten during the FS period were satisfying and of good quality. This was supported by the HDDS and IDDS with both scores being significantly lower during the food insecure period than the FS period $(t=4.47, p<0.0005)$ (Table 2$)$. There were significant differences among the villages in the number of meals, HDDS, and IDDS (Table 2). In both FS and FI periods, Kasonga registered the highest DDS, followed by Mpheta, Mtuluma, and Makombe. However, the difference was insignificant between Mpheta and Mtuluma. Makombe reported the lowest dietary diversity scores for both FS and FI periods.

Children complemented the meals taken in their homes with other foods outside their home, because the IDDS was always greater than the HDDS in all study sites and both food availability periods (Table 2). These other foods were consumed as meals or snacks at school, at the market, during play, and in their friends' homes. Snacks reported in children's food diaries included biscuits, sweets, drinks, and fruits (both wild and conventional fruits). There was a high correlation between a child's IDDS and household affluence, with children from better-off households reporting higher IDDS than children from poor households $(t=4.72: p<0.001)$.

\section{Diversity of Wild Foods Consumed by Children}

Every child participant in each village consumed at least one type of wild food, but there were inter- and intra-location variations. Across all four villages, the children recalled a total of 119 species (Fig. 1) (see Maseko 2015 for full list), with the largest groups being fruits (33\%), birds (20\%), and wild vegetables $(16 \%)$.

The lowest numbers of wild foods (44) were reported in Makombe and Mpheta where forest cover was the lowest. In contrast, 59 species were reported in Mtuluma and 48 in Kasonga (Fig. 2). However, the composition of the types of species varied. The Shannon-Weiner index for the two most forested villages (Mtuluma - 1.79; Kasonga - 1.78) were marginally higher than those for the two least forested villages (Makombe - 1.65; Mpheta - 1.63), indicating a higher diversity of wild foods. Wild fruits were the most species rich group in all villages except Mpheta, where wild birds were the most species rich group. In Mpheta, 33\% of all wild food species 
Table 2 Children's dietary patterns; number of meals a day, HDDS and IDDS

\begin{tabular}{|c|c|c|c|c|c|c|c|}
\hline \multirow[t]{2}{*}{ Measure } & \multirow{2}{*}{$\begin{array}{l}\text { Food secure or insecure } \\
\text { period }\end{array}$} & \multicolumn{4}{|l|}{ Village } & \multirow{2}{*}{$\begin{array}{l}\mathrm{F} \\
\text { value }\end{array}$} & \multirow[t]{2}{*}{$P$ value } \\
\hline & & $\begin{array}{l}\text { Makombe } \\
(n=28)\end{array}$ & $\begin{array}{l}\text { Kasonga } \\
(n=21)\end{array}$ & $\begin{array}{l}\text { Mtuluma } \\
(n=20)\end{array}$ & $\begin{array}{l}\text { Mpheta } \\
(n=52)\end{array}$ & & \\
\hline \multirow[t]{2}{*}{ Number of meals a day } & FS & 2.36 & 2.96 & 2.21 & 2.43 & 12.7 & $<0.0001$ \\
\hline & FI & 2.21 & 2.78 & 2.42 & 2.45 & 4.46 & $<0.01$ \\
\hline \multirow[t]{2}{*}{ HDDS (Food consum-ed in the home) } & FS & 3.18 & 4.96 & 3.53 & 3.61 & 7.99 & $<0.0001$ \\
\hline & FI & 2.57 & 3.48 & 3.05 & 3.06 & 3.82 & $<0.05$ \\
\hline \multirow{2}{*}{$\begin{array}{l}\text { IDDS (Food consum-ed in \& outside } \\
\text { the home) }\end{array}$} & FS & 3.71 & 5.52 & 4.11 & 4.22 & 6.98 & $<0.0005$ \\
\hline & FI & 2.86 & 4.17 & 3.53 & 3.55 & 4.57 & $<0.005$ \\
\hline
\end{tabular}

recalled by the children were birds and no bushmeat was reported for the village. On the other hand, 34\% of wild foods reported in Makombe were fruits, $25 \%$ were vegetables, $18 \%$ were birds, and the remainder bushmeat species (Fig. 2). There was no difference $(t=0.60 ; p=0.55)$ in the number of wild foods reported in group-rankings between boys $(7.3 \pm 3.4)$ and girls $(6.9 \pm 3.5)$, or by socioeconomic group ( $\mathrm{F}=2.49 ; p=0.07)$.

There was a weak positive relationship $\left(\mathrm{r}^{2}=0.062\right.$; $p=0.011$ ) between child age and the number of wild foods listed in three minutes (Fig. 3). Children aged ten years or younger listed on average $5.4 \pm 2.9$ wild foods, whilst those 15 or older listed approximately $50 \%$ more $(7.6 \pm 3.5)$.

\section{Wild Food Consumption during Food Secure and Food Insecure Periods}

On a 24 h recall basis, $23 \%$ of children consumed at least one wild food. However, over a longer period, captured by means of the weekly food diaries, $82 \%$ of children consumed at least one type of wild food during the FS and FI periods (Table 3). There was no variation in the overall proportion of children consuming wild foods during FS and the FI periods other than in Mpheta where no wild foods were listed during the food insecure period. However, wild vegetables were consumed more during the FI period (Table 3). During the FI periods,

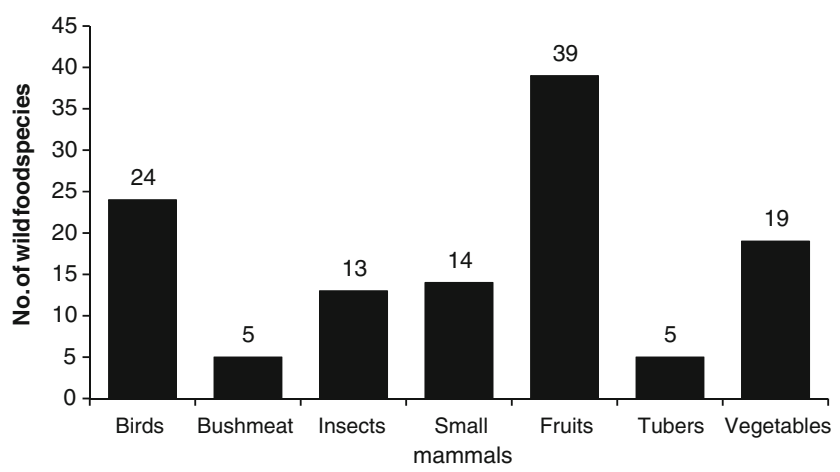

Fig. 1 Number of different types of wild food species identified by children in four villages in the Zomba district, Malawi some children relied strongly on wild food, such as insects or a mixed dish of wild vegetables as a meal. For example, one girl from Mpheta commented:

When we do not have other food, we grind okra to create flour and prepare it just as nsima, then we have it with Amaranthus as a relish. Sometimes we simply mix okra and Amaranthus to have a vegetable soup and take it as a meal.

Consumption of wild vegetables and wild fruits was common in all the sites with an average of $64 \%$ and $58 \%$ of children consuming wild vegetables and wild fruits, respectively. Over a seven day period wild vegetables were the most consumed food type, with $70 \%$ of children consuming them during the FI period and $58 \%$ during the FS period $\left(\chi^{2}=3.1\right.$; $p=0.08)$. Consumption of mushrooms was also higher during the FI period $(17 \%)$ than the FS period $(2 \%)\left(\chi^{2}=13.1\right.$; $p=0.0003)$. In contrast, there was little difference $\left(\chi^{2}=0.5\right.$; $p=0.47)$ in the consumption of wild fruits between the FS $(60 \%)$ and the FI (55\%) periods (Fig. 4).

Children commonly consumed a variety of bushmeat and small mammals in Kasonga, with a low frequency in both FS (11\%) and FI periods (13\%). These included hare, mice, duiker, monkey, and bushbuck. Consumption of crabs was also recorded in Kasonga and Mpheta, with $10 \%$ of children consuming them. On the other hand, consumption of insects was low $(2 \%)$ in all villages. Consumption of birds was common in Mpheta, with up to $11 \%$ of children eating birds during the FI period and $7 \%$ during the FS period $\left(\chi^{2}=1.0 ; p=0.32\right)$. Consumption of honey was reported in Kasonga.

There was a clear distinction in the consumption of wild foods, both in frequency and intensity (Table 4), over longer periods of time, such as a year. The children were asked how often they consume wild foods to determine the level of continued dependence or non-dependence on wild foods by. In all sites, wild vegetables were commonly eaten several times a month or several times a week. Only a few respondents stated that they never ate wild vegetables. Most children in Makombe, 
Fig. 2 Number of wild foods species identified by children at four villages in the Zomba district, Malawi

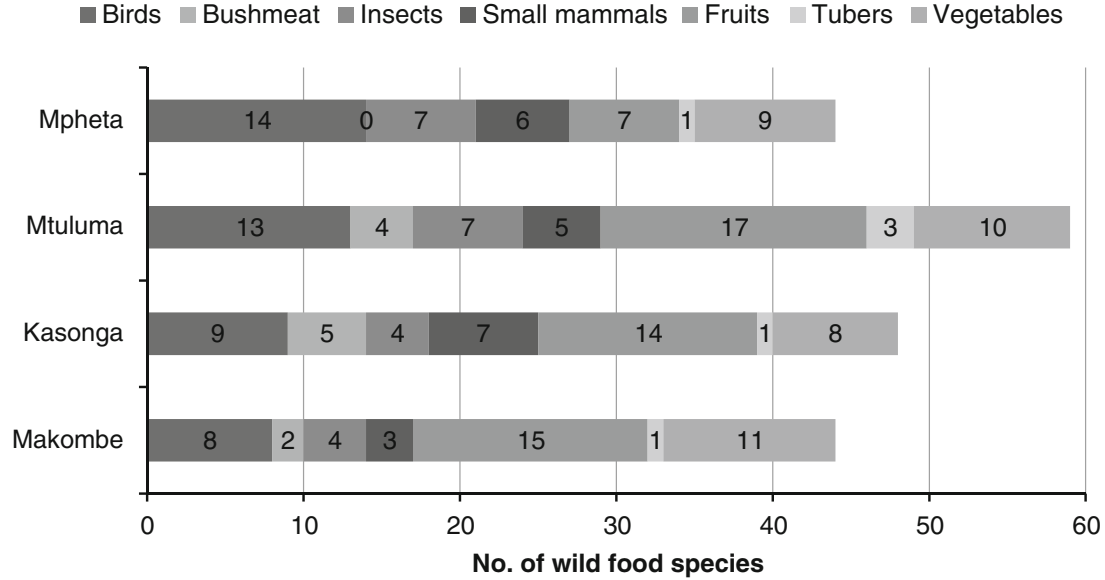

Kasonga, and Mtuluma reported consuming wild fruits. Children from Mtuluma reported the highest frequency in the consumption of wild fruits with at least $53 \%$ of children consuming them weekly, while $65 \%$ of children in Kasonga stated that they consumed wild fruits several times during the month. In Makombe, approximately one-third of children (35\%) consumed wild foods frequently, a slightly larger proportion (39\%) rated their frequency of consumption as low. In Mpheta, 38\% of children reported a low frequency in the consumption of wild fruits, and an additional $38 \%$ did not consume wild fruits. Across all sites, bushmeat was often consumed several times a year with highest frequencies in Kasonga and Makombe. Most (76\%) children in Mpheta did not consume bushmeat. However, birds and insects were commonly consumed several times a year in all study sites (Table 4).

\section{Wild Food Gathering and Consumption}

Children's consumption of wild foods was determined by several internal (those inspired by children) and external (those not made by children) factors (Table 5). Many children indicated that they consume wild foods because the foods contribute positively to their nutritional status and "give them good health." According to the children, wild foods were fattening,

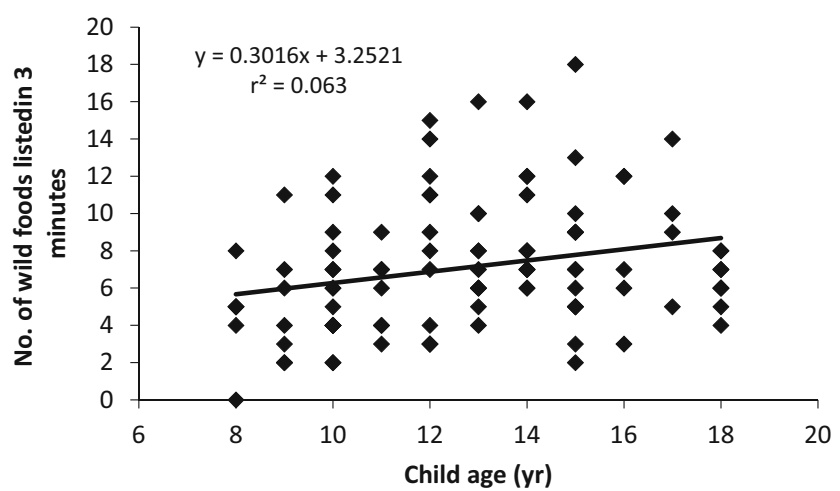

Fig. 3 The number of wild foods listed in three minutes by children of different ages in four villages in Zomba district, Malawi provide energy and strength, protect the body from diseases, and supplement the blood. In addition, the children said that wild foods provide nutrients such as iron, carbohydrates, vitamins, and proteins. Forty-five percent indicated that wild fruits provide good health and nutrition, with the corresponding figure for wild vegetables being $28 \%$. While older children (13-18 years old) were able to provide some details regarding the nutritional information of wild foods, younger children (8-13 years old) simply indicated that the wild foods contribute to good health. Some children also indicated that they consume wild foods to satisfy the six food groups to be healthy, as taught at school.

On the other hand, some wild foods, such as some insects, birds, and bushmeat, were consumed because they were regarded as delicious and provide variety to the diet and are locally termed "zakudya za nkhwiru" (a delicacy; nutritionally valuable and tastier) (Table 5). This was common for animalbased wild foods. They are considered a delicacy and provide alternatives to commonly consumed side-dishes, at the same time providing fats and proteins.

Convenience was another reason that influenced children's use of wild foods. It was clear that children considered wild fruits to be tasty and sweet and was a common snack to take when hungry and fruits were observed (Table 5). When children go to school, for play, to fetch firewood or water, to conduct farm activities or go to the market, they consume wild fruits along the way.

A lack of other alternative foods in the household was also mentioned as a factor prompting some children to collect and consume wild foods, suggesting that household socioeconomic status plays a role. Thirty-three percent of children stated that they consumed wild vegetables because their household lacked other alternatives (Table 5).

A number of reasons were provided by some children for not consuming certain types of wild foods. The first was that they disliked the taste or smell. For instance, Aloe meynharthii and Bidens are not consumed by some children because they taste bitter, while to others, Amaranthus species had an 
Table 3 Wild foods commonly consumed by children during a one week period during the food secure (FS) and food insecure (FI) in the four study villages

\begin{tabular}{|c|c|c|c|c|c|c|c|c|c|}
\hline \multirow[t]{2}{*}{ Wild food type } & \multirow[t]{2}{*}{ Species } & \multicolumn{2}{|c|}{ Makombe } & \multicolumn{2}{|c|}{ Kasonga } & \multicolumn{2}{|c|}{ Mtuluma } & \multicolumn{2}{|c|}{ Mpheta } \\
\hline & & FS & FI & FS & FI & FS & FI & FS & FI \\
\hline \multirow[t]{9}{*}{ Vegetables \& mushrooms } & Aloe meynharthii & 0 & 0 & 1 & 3 & 0 & 0 & 0 & 0 \\
\hline & Alternanthera pungens & 0 & 0 & 0 & 0 & 0 & 0 & 7 & 0 \\
\hline & Amaranthus spinosus \& hybridus & 2 & 7 & 0 & 2 & 0 & 3 & 4 & 0 \\
\hline & Bidens pilosa & 0 & 0 & 4 & 2 & 3 & 0 & 3 & 0 \\
\hline & Cleome gynandra & 3 & 0 & 0 & 0 & 1 & 2 & 0 & 0 \\
\hline & Cleome monophylla & 0 & 0 & 0 & 0 & 1 & 1 & 0 & 0 \\
\hline & Cochorus trilocularis & 3 & 4 & 1 & 2 & 5 & 2 & 3 & 0 \\
\hline & Galinsonga parviflora & 0 & 0 & 2 & 0 & 0 & 0 & 0 & 0 \\
\hline & Mushrooms & 0 & 0 & 0 & 3 & 1 & 0 & 0 & 0 \\
\hline \multirow[t]{11}{*}{ Fruits } & Adansonia digitata & 1 & 0 & 1 & 0 & 0 & 0 & 3 & 0 \\
\hline & Anclylobathrys amoena & 2 & 2 & 0 & 0 & 0 & 0 & 0 & 0 \\
\hline & Annona senegalensis & 5 & 0 & 0 & 0 & 2 & 1 & 1 & 0 \\
\hline & Flacourtia indica & 1 & 0 & 0 & 0 & 4 & 5 & 0 & 0 \\
\hline & Landolphia buchananii & 0 & 0 & 3 & 0 & 0 & 0 & 0 & 0 \\
\hline & Sclerocarya birrea & 0 & 0 & 0 & 0 & 0 & 0 & 2 & 0 \\
\hline & Uapaca kirkiana & 0 & 0 & 1 & 0 & 1 & 1 & 0 & 0 \\
\hline & Vangueria infausta & 2 & 3 & 0 & 0 & 2 & 1 & 0 & 0 \\
\hline & Vitex domiana & 0 & 0 & 0 & 0 & 1 & 0 & 1 & 0 \\
\hline & Ziziphus mauritania & 0 & 0 & 0 & 0 & 1 & 0 & 3 & 0 \\
\hline & & \multicolumn{2}{|c|}{$t=0.29 ; p=0.77$} & \multicolumn{2}{|c|}{$\begin{array}{l}t=0.14 \\
p=0.89\end{array}$} & \multicolumn{2}{|c|}{$\begin{array}{l}t=0.69 \\
p=0.49\end{array}$} & \multicolumn{2}{|c|}{$\begin{array}{l}t=3.17 \\
p=0.003\end{array}$} \\
\hline
\end{tabular}

unpleasant smell. Nevertheless, when asked by their parents to collect these vegetables, they complied. Secondly, some children indicated that they do not consume particular wild foods due to medical reasons. For instance, some girls do not consume Bidens because they suffer from what is culturally known as "mutu waukulu" (migraine). Thirdly, a common reason was the perceived stigma associated with some wild foods. During focus group discussions, one girl indicated that, "some children do consume the mentioned wild foods in their homes but are too shy to reveal and are afraid that others will

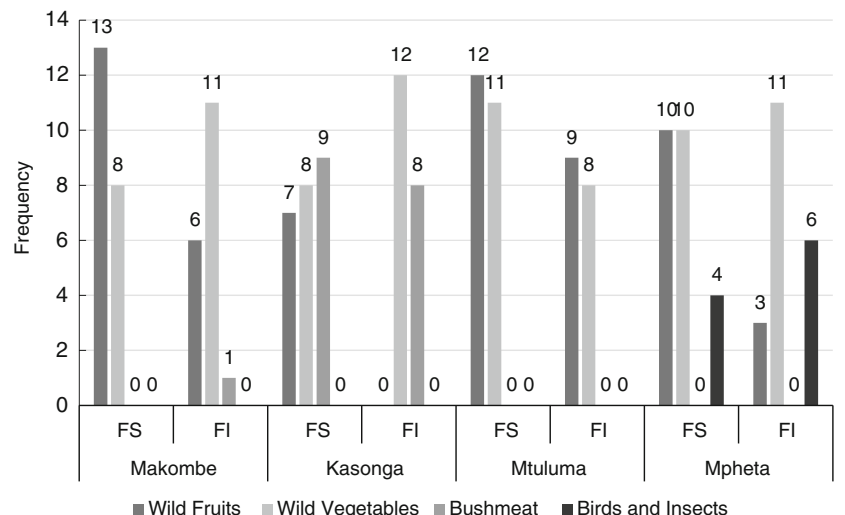

Fig. 4 Consumption of wild foods by children in a $24 \mathrm{~h}$ period during food secure (FS) and insecure (FI) periods in the four study villages laugh at them." These notions differed between wild foods in different sites indicating that perceptions of wild foods are mediated by sociocultural norms.

While one wild food was associated with the "poverty complex" at one site, the same food might be highly valued at another site. For example, mice and vervet monkeys were considered food for the poor in Makombe, whilst some children in Kasonga considered them delicacies. Similarly, wild foods that were deemed to be associated with poverty in Kasonga (such as Bidens and Amaranthus) were highly valued and commonly consumed in Mtuluma. Lastly, some children mentioned particular beliefs, taboos and faith. For instance, it was stated that most Muslim children do not consume mice, whereas some children in Mtuluma indicated that they do not consume vervet monkeys because they resemble humans. On the other hand, some children from Kasonga and Makombe did not consume caterpillars because they felt that they looked scary.

All children in all study sites consumed at least one or more types of wild foods but there were inter-and intra-location variations in wild food use. There were clear similarities in the consumption patterns of certain wild foods (such as wild fruits) from children who lived near each other by comparing their food diaries hence suggesting that these wild foods were consumed as snacks outside their homes. The food diaries also revealed that some wild foods such as wild vegetables, 
Table 4 The percentage of children in four villages reporting a given frequency of wild food consumption within a year

\begin{tabular}{|c|c|c|c|c|c|}
\hline $\begin{array}{l}\text { Wild food } \\
\text { type }\end{array}$ & $\begin{array}{l}\text { Time period } \\
\text { interval }\end{array}$ & Makombe & Kasonga & Mtuluma & Mpheta \\
\hline \multirow[t]{4}{*}{ Vegetables } & $\begin{array}{l}\text { Several times } \\
\text { a week }\end{array}$ & 31.8 & 40.0 & 35.3 & 32.4 \\
\hline & $\begin{array}{l}\text { Several times } \\
\text { a month }\end{array}$ & 54.6 & 45.0 & 41.2 & 38.6 \\
\hline & $\begin{array}{l}\text { Several times } \\
\text { a year }\end{array}$ & 9.1 & 5.0 & 17.6 & 13.5 \\
\hline & Never & 4.5 & 10.0 & 5.9 & 5.4 \\
\hline \multirow[t]{4}{*}{ Fruits } & $\begin{array}{l}\text { Several times } \\
\text { a week }\end{array}$ & 34.6 & 20.0 & 53.0 & 8.1 \\
\hline & $\begin{array}{l}\text { Several times } \\
\text { a month }\end{array}$ & 15.3 & 65.0 & 4.2 & 16.2 \\
\hline & $\begin{array}{l}\text { Several times } \\
\text { a year }\end{array}$ & 38.5 & 10.0 & 5.9 & 37.8 \\
\hline & Never & 1.5 & 5.0 & 0.0 & 37.8 \\
\hline \multirow[t]{4}{*}{ Bushmeat } & $\begin{array}{l}\text { Several times } \\
\text { a week }\end{array}$ & 11.5 & 5.0 & 0.0 & 2.7 \\
\hline & $\begin{array}{l}\text { Several times } \\
\text { a month }\end{array}$ & 19.2 & 30.0 & 5.9 & 10.8 \\
\hline & $\begin{array}{l}\text { Several times } \\
\text { a year }\end{array}$ & 23.1 & 55.0 & 52.9 & 10.8 \\
\hline & Never & 46.2 & 10.0 & 41.2 & 75.6 \\
\hline \multirow[t]{4}{*}{$\begin{array}{l}\text { Birds and } \\
\text { insects }\end{array}$} & $\begin{array}{l}\text { Several times } \\
\text { a week }\end{array}$ & 0.0 & 10.0 & 11.8 & 8.1 \\
\hline & $\begin{array}{l}\text { Several times } \\
\text { a month }\end{array}$ & 33.3 & 20.0 & 35.2 & 13.5 \\
\hline & $\begin{array}{l}\text { Several times } \\
\text { a year }\end{array}$ & 55.6 & 50.0 & 35.3 & 59.4 \\
\hline & Never & 11.1 & 20.0 & 17.6 & 18.9 \\
\hline
\end{tabular}

bushmeat, some birds and insects, were taken as part of the meals as side dishes and complimented cereals or in some cases consumed solely.

The trends in the frequency in consumption of wild foods by children across the study sites and between different food categories differed. In all study sites, wild vegetables were commonly taken several times a month or several times a week. Only a few respondents admitted to never eating wild vegetables. Most children in Makombe, Kasonga and Mtuluma

Table 5 The percentage of children mentioning particular reasons underlying their consumption of different wild foods

\begin{tabular}{lllll}
\hline Reason & Birds/insects & Bushmeat & Fruits & Vegetables \\
\hline Nutritious & 26 & 16 & 16 & 18 \\
Good health & 2 & 3 & 17 & 10 \\
Provide energy & 3 & 1 & 12 & 11 \\
Tasty \& convenient & 17 & 12 & 19 & 8 \\
Lack of alternatives & 16 & 5 & 1 & 33 \\
Poverty & & & & 3 \\
Hunger & & 13 & 15 & 10 \\
No particular reason & 22 & &
\end{tabular}

reported consuming wild fruits. Children from Mtuluma reported the highest frequency in the consumption of wild fruits with at least $53 \%$ of children consuming them weekly while children $(65 \%)$ in Kasonga consumed wild fruits several times during the month. In Makombe, while some children (35\%) consumed wild foods more frequently, other children's frequency in consumption was low (39\%). In Mpheta, 38\% of children reported a low frequency in the consumption of wild fruits, and an additional $38 \%$ did not consume the fruits at any time in a year. Most children in Kasonga consumed bushmeat and the village recorded the highest frequency of consumption. Across all sites, bushmeat was often consumed several times a year with highest frequency in Kasonga and Makombe. Most (76\%) children in Mpheta did not consume bushmeat and the lowest frequency in consumption was reported in the village. Similarly, birds and insects were commonly consumed several times a year in all study sites.

\section{Commercialisation of Wild Foods by Children}

In each village, some children sell one or more types of wild foods, ranging from 14\% of households in Makombe to 35\% in Kasonga, and $37 \%$ in both Mtuluma and Mpheta. Poverty appears to be a significant driver of engagement in the sale of wild foods because $40 \%$ of children from poor households stated they sell wild foods, whereas only $7 \%$ of children from the better-off households did $\left(\chi^{2}=30.3 ; p<0.0001\right)$.

Wild fruits are the most common wild food sold by children (18\%), with trade in Uapaca kirkiana being the most widespread. Children in Kasonga sold Uapaca kirkiana at the local market and tourist destination sites on Zomba Plateau, where a plate of Uapaca kirkiana is sold for on average between MK500 - MK2000 ( \pm US 10 - 40c) depending on how wealthy the tourist appears, but sells for only M K50 in the local market. Children in Kasonga and Mtuluma also sell mushrooms. A wide variety of wild vegetables are sold by children at the local markets, with the most common being Amaranthus in all villages and tubers (Chikande; Disa sp.) in Kasonga.

Children participate in the sale of wild foods for several reasons: mainly to obtain basic items and utilities for the household (33\%), personal items (29\%), supplement food (21\%), and purchase school items (17\%). Household basic items include groceries for the household such as soap, sugar, salt, matches, and cooking oil. Individual items purchased include clothes, body oils/lotion, and snacks for themselves, whereas school materials included notebooks, pens, and pencils.

\section{Discussion}

The gathering and consumption of wild foods are highly diverse activities with respect to species harvested, locations, purposes, preferences, and collection habits. Gathering ranges 
from infrequent and ad hoc collection during the course of other activities, through to purposeful and extensive collection for the household table or for sale to earn income. As such, it was influenced by a number of factors, including food security of the household (children gathered more during food insecure periods), convenience of gathering, availability, alternatives, and personal attributes such as age and taste preferences. It is clear that this diversity requires greater investigation and disaggregation. The most important would be to understand contextual factors because they are shaped by broader social and economic influences and decisions that may unwittingly affect food availability; for example deforestation.

Social connections are important for wild food gathering practices, as children often learn from their elders and peers about locations to gather and the different varieties of wild foods. As reported elsewhere (Challe and Price 2009), children often accompany elders to gather wild foods and are taught about particular wild food species and their cultural significance (if any). Forty-three per cent of children indicated that they learned of wild foods from their mothers while $24 \%$ acquired this knowledge from their grandparents. Peer-group learning was also extensive as children frequently play in and explore local environments in groups.

Our study reveals the low dietary diversity of households and children in the four villages, with HDDS being below four in all but one instance, and IDDS mostly below five. Narratives from the children's food diaries and focus groups corroborated this, with a standard meal being nsima (maize porridge) with or without a side relish. Consequently, consumption of wild foods adds significantly to dietary diversity. On a $24-\mathrm{h}$ recall basis, $23 \%$ of participants had consumed wild foods. When measured over a full week, $82 \%$ had consumed wild food, and when asked about consumption frequencies of a full year every child reported that they eat wild foods. Thus, dietary diversity is increased through the consumption of wild foods, which likely contributes positively to higher nutrient adequacy and nutrient density across multiple nutrients (Powell et al. 2011). A wide diversity of wild food species were identified by the children, totaling 119 different species, ranging from 44 to 59 across the four villages. We view these as conservative counts as the surveys and transect walks did not span all seasons of the year. The two villages currently with the highest forest cover had the highest number of wild food species listed by children and the highest diversity (Shannon-Weiner index), and the two with the least forest cover had the lowest total number and diversity, corroborating the findings of Ickowitz et al. (2013). Wild fruit comprised the largest number of species (39), followed by birds (24) and wild vegetables (19). However, the proportional contributions of different wild food types were not uniform across the four villages. The proximity of Kasonga to the Zomba forest reserve may have contributed to the greater number of animal wild foods there. Likewise, we interpret the large number of bird species listed for Mpheta to be a reflection of it being adjacent to Lake Chilwa, which supports large populations of resident and migratory water birds (Mgoola 2007). The two villages with the highest tree cover tended to have more bushmeat and fruit species, whereas the two with the least forest cover had the most vegetable species, suggesting that the effects of deforestation were not uniform across wild food types.

Although the DDS were higher in the FS period than the FI, we found no difference in the incidence of wild food consumption between these two periods, except in Mpheta, where very few species were listed during the food insecure period. Previous research in other southern African countries has revealed differential use and dependence on wild foods during different seasons and in response to food scarcity and periods of household shock (Hunter et al. 2007; McGarry and Shackleton 2009b; Chidumayo and Marunda 2010; Ncube et al. 2016). In Malawi, Fisher et al. (2010) report that forest dependent communities made up to five times greater use of forest resources, including wild foods, during climate related shocks, such as droughts. Of the foods consumed only during famine periods, $25 \%$ are wild foods, and mpama, a drought resistant forest yam, is often used (Fisher et al. 2010). Our finding that wild food consumption is no different during the FS and the FI periods may be a reflection of the seasonal availability of some species and/or different needs of household labour in those seasons.

The main reasons children gave for consuming wild foods were good health and nutrition. The respondents indicated that wild foods supplement their diet, prevent diseases, provide energy, and provide proteins and vitamins. However, this study could not determine if this knowledge affects their selection and use of wild food and their overall interest them. There is sufficient information on the superior nutritional value of selected wild foods (Campbell 1987; Grivetti and Ogle 2000; Kajembe et al. 2000). Such information is, however, available for only a few common species, while the nutritional value of many species remains unknown (Ruffo et al. 2002). In addition, children described certain wild foods, especially protein sources such as bushmeat and insects, as delicacies and highly sought after. Knowledge of the health benefits of wild foods could lead to increased consumption of wild foods with concomitant improved nutritional outcomes (Cordeiro 2012).

The importance of wild foods to children (and households) was further demonstrated through one-third of the children reporting at times selling wild foods on local markets and to tourists, and this activity is more common amongst poorer households. Local trade in wild foods has been extensively reported in southern Africa, although rarely acknowledged or aided by authorities. Participation of children in such trade has been noted in other studies (Shackleton 2004; Challe and Price 2009; McGarry and Shackleton 2009a), but the real extent and financial benefits to children and their households have not been systematically investigated. 


\section{Conclusion}

Most households in the four villages have diets of low diversity, dominated by maize porridge dishes. Much of this diversity is provided by wild foods, of which a large number of species are consumed across a range of food types. Children actively participate in the collection and hunting of wild foods, their consumption and trade. The differences according to deforestation status were not marked, with children making use of what wild resources were suited to the local habitats. However, use of larger wild game species and wild fruit was reduced in areas with low forest cover. Small game, insects, some wild fruits and wild vegetables thrive well in agroecosystems and therefore were minimally affected by deforestation but rather by management practices of those systems, and their abundance can possibly be improved through the promotion of agro-ecological farming systems.

\begin{abstract}
Acknowledgements We acknowledge financial contributions for the fieldwork and bursary (to HM) from the ASSETS project funded under the ESPA programme of NERC and DFID, as well as the National Research Foundation (South Africa). We are grateful to Dr. Dalitso Kafumbata and to Nafy, Bessie, Maggie, and Peter for field assistance, and M. Patella for identification of plant specimens. Our heartfelt appreciation goes to the children and communities of Makombe, Kasonga, Mtuluma, and Mpheta for welcoming us into their homes and community.
\end{abstract}

Funding We acknowledge financial contributions for the fieldwork and bursary (to HM) from the ASSETS project funded under the ESPA programme of NERC and DFID, as well as the National Research Foundation (South Africa).

\section{Compliance with Ethical Standards}

Conflict of Interest All authors declare that they have no conflicts of interest pertaining to this work.

Informed Consent The work complied with best practice ethical guides and ethics approval was granted via Rhodes University. Since the research involved minors, informed consent was obtained from parents or guardians.

\section{References}

Alexander J., Cocks M., and Shackleton C. M. (2015). The Landscape of Childhood: Play and Place as Tools to Understanding Children's Environmental Use and Perceptions. Human Ecology 43: 467-480.

Assembly Z. D. (2009). Zomba Socio-Economic Profile, 2009-2012, Zomba District Assembly, Zomba.

Bharucha Z., and Pretty J. (2010). The Roles and Values of Wild Foods in Agricultural Systems. Philisophical Transactions of the Royal Society. Biological Sciences 365: 2913-2926.

Broegaard R. B., Rasmussen L. V., Dawson N., Mertz O., Vongvisouk T., and Grogan K. (2016). Wild Food Collection and Nutrition Under Commercial Agriculture Expansion in agriculTure-Forest Landscapes. Forest Policy \& Economics. https://doi.org/10.1016/j. forpol.2016.12.012.
Campbell B. M. (1987). The Use of Wild Fruits in Zimbabwe. Economic Botany 41: 375-385.

Cavendish W. (2000). Empirical regularities in the poverty-environment relationship of rural households: evidence from Zimbabwe. World Development 28: 1979-2003.

Challe J. F. X., and Price L. L. (2009). Endangered Edible Orchids and Vulnerable Gatherers in the Context of HIV/AIDS in the Southern Highlands of Tanzania. Journal of Ethnobiology \& Ethnomedicine 5: 41-52.

Chidumayo E. N., and Marunda C. (2010). Dry Forests and Woodlands in Sub-Saharan Africa: Context and Challenges. In Chidumayo E. N., and Gumbo D. J. (eds.), The Dry Forests and Woodlands of Africa. Earthscan, London, pp. 1-10.

Chilimba A., Young A. D., Black C., Maechan M., Lammel J., and Broadley M. (2012). Agronomic Biofortification of Maize with Selenium (Se) in Malawi. Field Crops Research 115: 118-128.

Chirwa E. W., and Ngalawa H. P. (2008). Determinants of Child Nutrition in Malawi. Southern Africa. Journal of Economics 76: 628-640.

Cordeiro L. (2012). Household Dietary Diversity, Wild Edible Plants and Diarrhoea Among Rural Households in Tanzania. Journal of medicinally active. Plants $1: 10-27$.

Damman S., Eide W. B., and Kuhnlein H. V. (2008). Indigenous peoples' nutrition transition in a right to food perspective. Food Policy 33: $135-155$.

Department of Nutrition, HIV and AIDS (2009). National Nutrition Policy And Strategic Plan, Office of the President and Cabinet, Lilongwe.

Ecker O., and Qaim M. (2010). Analysing Nutritional Impacts Of Policies: An Empirical Study for Malawi, International Food Policy Research Institute, Lilongwe.

FAO (2010). Global Forest Resources Assessment: Main Report, FAO, Rome.

FAO (2011). Guidelines for Measuring Household and Individual Dietary Diversity, FAO, Rome.

FAOSTAT. (2017). Malawi - Country Indicators. Online http://www.fao. org/faostat/en/\#country/130 Accessed on May 2017.

Fisher M., Chaudhury M., and McCusker B. (2010). Do Forests Help Rural Households Adapt to Climate Variability? Evidence from Southern Malawi. World Development 38: 1241-1250.

Garcia G. S. (2006). The mother-child nexus. knowledge and valuation of wild food plants in Wayanad, Western Ghats, India. Journal of Ethnobiology and Ethnomedicine 2(39). Online. https://doi.org/10. 1186/1746-4269-2-39.

Government of Malawi (2016). Demographic and Health Survey (2015), National Statistical Office, Zomba.

Grivetti L. E., and Ogle B. M. (2000). Value of Traditional Foods in Meeting Macro- and Micronutrient Needs: The Wild Plant Connection. Nutrition Research Reviews 13: 31-46.

Heubach K., Wittig R., Nuppenau E., and Hahn K. (2011). The Economic Importance of Non-Timber Forest Products (NTFPs) for Livelihood Maintenance of Rural West African Communities: A case Study from Northern Benin. Ecological Economics 70: 1991-2000.

Hunter L. M., Twine W., and Patterson L. (2007). Locusts are Now Our Beef': Adult Mortality and Household Dietary Use of Local Environmental Resources in Rural South Africa. Scandinavian Journal of Public Health 35: 165-174.

Ickowitz A., Powell B., Salim A. M., and Sunderland T. C. H. (2013). Dietary Quality and Tree Cover in Africa. Global Environmental Change 24: 287-294.

Jonhson K.B., Jacob A. and Brown M. E. (2013). Forest cover associated with improved child health and nutrition: evidence from Malawi demographic and health survey and satellite data. Global Health, Science and Practice 1(2): 237-248.

Kajembe, G. C., Mwenduwa, M. I., Mgoo, J. S., and Ramadhani, H. (2000). Potentials of Non Wood Forest Products in Household Forest Security in Tanzania: The Role of Gender Based Local Knowledge. Gender, Biodiiversity and Local Knowledge Systems 
(LinKS) to Strength Agricultural and Rural Development (GCP/ $\mathrm{RAF} / 338 / \mathrm{NOR}$ ).

Kalaba F. K. (2007). The role of indigenous fruit trees in rural livelihoods: the case of communities around the Mwekera area, Cooperbelt province, Zambia. MSc thesis, University of Stellenbosch, Stellenbosch.

Kamanga P., Vedeld P., and Sjaastad E. (2009). Forest Incomes and Rural Livelihoods in Chiradzulu District Malawi. Ecological Economics 68: 613-624.

Kerr R. B., Chilanga B., Nyantakyi-Frompong H., Luginaah I., and Lupafya E. (2016). Integrated Agriculture Programs to Address Malnutrition in Northern Malawi. BMC Public Health 16: 1-14.

Kidane B., van der Maesen L. J., Asfaw Z., Sosef M. F., and van Andel T. (2015). Wild and Semi-Wild Leafy Vegetables Used by the Maale and Ari Ethnic Communities in Southern Ethiopia. Genetic Resources \& Crop Evolution 62: 221-234.

Lowore J. (2006). Miombo woodlands and rural livelihoods in Malawi. Centre for International Forestry Research (CIFOR), Bogor.

Maliro M. F., and Kwapata M. B. (2002). Impact of Deforestation on Diversity of Wild and Semi-Wild Edible Fruit Tree Species in Southern Malawi. Discovery \& Innovation 14: 98-105.

Maroyi A. (2011). The Gathering and Consumption of Wild Edible Plants in Nhema communal area, Midlands Province, Zimbabwe. Ecology of food. Nutrition 50: 506-525.

Maseko H. (2015). The Consumption and Use of Wild Foods by children across a deforestation gradient in Zomba District, Malawi. In Masters thesis, Rhodes University, Grahamstown.

Mazunda J., and Droppelmann K. (2012). Maize Consumption Estimation and Dietary Diversity Assessment Methods in Malawi, Policy Note, International Food Policy Research Institute, Lilongwe.

McGarry D. K., and Shackleton C. M. (2009a). Children Navigating Rural Poverty: Rural Children's Use of Wild Resources to Counteract Food Insecurity in the Eastern Cape Province, South Africa. Journal of Children \& Poverty 15: 19-37.

McGarry D. K., and Shackleton C. M. (2009b). Is HIV/AIDS Jeopardising Biodiversity? Environmental Conservation 36: 5-7.

McLain R. J., Hurley P. T., Emery M. R., and Poe M. R. (2014). Gathering "Wild" Food in the City: Rethinking the Role of Foraging in Urban Ecosystem Planning and Management. Local Environment 19: 220-240.

Mgoola W. O. (2007). Assessment of the Biological Impact of Bird Hunting in the Lake Chilwa Wetland, University of Malawi, Chancellor College, Zomba, MSc Thesis.

Ministry of Environment and Natural Resources. (2010). State of Environmental Outlook Report. Ministry of Environment and Natural Resources, Lilongwe.

National Statistics Office (NSO). (2014). Zomba: MDG Endline Survey 2014 Key Findings. Online publication available at http://www. nsomalawi.mw/images/stories/data on line/demography/MDG\% 20Endline/district_key_findings_reports/MES_Zomba.pdf Accessed on 14 October 2017

Ncube K., Shackleton C. M., Swallow B. M., and Dassanayake W. (2016). Impacts of HIV/AIDS on Food Consumption and Wild Food Use in Rural South Africa. Food Security 8: 1135-1151.

Ngongondo C. S. (2006). An Analysis of Long-Term Rainfall Variability, Trends and Groundwater Availability in the Mulunguzi River Catchment Area, Zomba Mountain, Southern Malawi. Quaternary International 148: 45-50.

Paumgarten F., and Shacketon C. M. (2009). Wealth Differentials in the Use and Trade of Local Non-Timber Forest Productsas Safety Nets. Ecological Economics 68: 2950-2959.

Pingali P. (2007). Westernisation of Asian Diets and the Transformation of Food Systems: Implications for Research and Policy. Food Policy 32: 281-298

Poppy G., Chiotha S., Eigenbrod F., Harvey C., Honzak M., Hudson M., Jarvis A., Madise N., Schreckenberg K., Shackleton C., Villa F., and
Dawson T. (2014). Understanding Food Security in a Perfect Storm: An Ecosystem Services Approach. Philosophical Transactions of the Royal Society B 369: 20120288. https://doi.org/10.1098/rstb. 2012.0288 .

Powell B., Hall J., and Johns T. (2011). Forest Cover, Use and Dietary Intake in the East Usambara Mountains, Tanzania. International Forest Review 13: 1-13.

Powell, B., Ouarghidi, A., Johns, T., Ibn Tattou, N., and Eyzaguirre, P. (2014). Wild Leafy Vegetable Use and Knowledge Across Multiple Sikte Sin Morocco: A Case Study for Transmission of Local Knowledge. Journal of Ethnobiology \& Ethnomedicine, 10(1): 34 online.

Ruffo C. K., Birnie A., and Tengnas B. (2002). Edible wild plants of Tanzania, Regional land management unit, Swedish International Development Cooperation Agency, Kenya.

Schreckenberg K. (1999). Products of a Managed Landscape: NonTimber Forest Products in the Parklands of the Bassila Region, Benin. Global Ecology \& Biogeography 8: 279-289.

Scoones I., Melnyk R., and Pretty J. N. (1992). The hidden harvest: wild foods in agricultural systems: a literature review and annotated bibliography. International Institute of Environment and Development London, pp. 256.

Setalaphruk, C., and Price, L. L. (2007). Children's Traditional Ecological Knowledge of Wild Food Resources: A Case Study in a Rural Village in Northeast Thailand. Journal of Ethnobiology \& Ethnomedicine 3:33 online. doi: https://doi.org/10.1186/17464269-3-33.

Shackleton S. E. (2004). Livelihood Benefits From The Local Level Commercialisation of Savanna Resources: A Case Study of the New and Expanding Trade In Marula (Sclerocarya Birrea) Beer in Bushbuckridge. South Africa. South African Journal of Science 100: 651-657.

Shackleton S., and Gumbo, D. (2010). Contribution of non-wood forest products to livelihoods and poverty alleviation. In: E.N. Chidumayo and D.J. Gumbo (Eds.), The dry forests and woodlands of Africa: managing for products and services. London: Earthscan, pp. 64-92.

Shackleton C. M., Paumgarten F., and Cocks M. L. (2008). Household Attributes and Homestead Tree Holdings in Semi-Arid Rural Areas, South Africa. Agroforestry Systems 72: 221-230.

Swindale, A., and Bilinsky, P. (2006). Household Dietary Diversity Score (HDDS) for Measurement of Household Food Access: Indicator Guide, Ver. 2. Food and Nutrition Technical Assistance Project, Academy for Educational Development, Washington, D.C.

Syampungani S., Chirwa P. W., Akinnifesi F. K., Sileshi G. and Ajayi O. C. (2009). The miombo woodlands at the cross roads: potential threats, sustainable livelihoods, policy gaps and challenges. Natural Resources Forum, 33: 150-159.

Sylvester O., García Segura A., and Davidson-Hunt I. J. (2016). Wild Food Harvesting and Access by Household and Generation in the Talamanca Bribri Indigenous Territory, Costa Rica. Human Ecology 44: 449-461.

Tata-Ngome P. I. (2016). The Contribution of Fruit From Trees to Improve Household Nutritional security in the Context of Deforestation in Cameroon. In PhD thesis, Rhodes University, Grahamstown.

Timko J. A. (2013). Exploring Forest-Related Coping Strategies for Alleviating the HIV/AIDS Burden on Rural Malawian Households. International Forestry Review 15: 230-240.

UN-HABITAT. (2011). Malawi: Zomba Urban Profile. Online http:// mirror.unhabitat.org/pmss/getElectronicVersion.aspx? $\mathrm{nr}=$ 3170\&alt $=1$ Accessed 10 May 2017.

Uusiku N. P., Oelofse A., Duodu K., Bester M., and Faber M. (2010). Nutritional Value of Leafy Vegetables of Sub-Saharan Africa and their Potential Contribution to Human Health: A review. Journal of Food Composition \& Analysis 23: 499-509.

Van Noordwijk M., Bizard V., Wangpakapattanawong P., Tata H. L., Villamor G. B., and Leimona B. (2014). Tree cover Transitions 
and Food Security in Southeast Asia. Global Food Security 3: 200 208.

van Vliet, N., Quiceno-Mesa, M. P., Cruz-Antia, D., Tellez, L., Martins, C., Haiden, E., Ribeiro Oliveira, M., Adams, C., Morsello, C., Valencia, L., Bonilla, T., Yagüe, B., and Nasi, R. (2015a). From Fish and Bushmeat to Chicken Nuggets: The Nutrition Transition in a Continuum from Rural to Urban Settings in the Tri-frontier
Amazon Region. Ethnobiology \& Conservation, https://oi.org/10. 15451/ec2015-7-4.6-1-12.

Van Vliet N., Nebesse C., and Nasi R. (2015b). Bushmeat Consumption Among Rural and Urban Children from Province Orientale, Democratic Republic of Congo. Oryx 49: 165-174.

Vaughan M. (2007). Book review: a history of food and everyday life in Malawi, 1860-2004. Journal of Southern African Studies, 33: 209-211. 